\title{
Disseminated insect bite reactions in hazelnut workers
}

\author{
Fındık ișçilerinde gözlenen dissemine böcek ısırığı reaksiyonları
}

\section{Ișıl Deniz Oğuz, ๑ Sevgi Kulaklı, ๑ Burak Akșan}

Giresun University Faculty of Medicine, Department of Dermatology, Giresun, Turkey

\begin{abstract}
Background and Design: Hazelnut is one of the most important agricultural products of Turkey. About 150 species of insects were reported in hazelnut orchards. Several skin reactions can be seen in hazelnut workers due to contact with the insects. The objective of this study is to investigate the clinical properties of a type of disseminated insect bite reaction detected in hazelnut workers that has not been reported yet. Materials and Methods: In our study, we investigated patients who presented to our outpatient clinic with disseminated insect bite reactions after entering hazelnut orchards prospectively. Patients' age, gender, clinical properties of lesions, body areas of involvement, number of lesions, subjective symptoms, duration, blood groups, and prescribed treatments were recorded. The features of the hazelnut orchards were also recorded.

Results: One hundred and twenty-seven patients ( 45 males; 82 females) were included in the study. Mean age of the patients was $42.5 \pm 16.69$ years. Lesion placements were mostly on the hip (88.2\%), leg (78.7\%), and back-waist (72.4\%) areas. Eighty-five percentage of the patients had violaceous papules, $10.2 \%$ showed papular urticaria, and $4.7 \%$ with vasculitis-like purpuric papules. Fifty-nine percentage of the patients had between zero and 50 lesions, $28.4 \%$ had 50 and 100 , and $12.6 \%$ of the patients had more than 100 lesions. Severe pruritus was seen in $97.6 \%$ of the patients.

Conclusion: Insect bite reactions are severe health issues in hazelnut workers. There are limited studies on arthropod-induced dermatoses in hazelnut orchards. However, we demonstrated a novel insect bite reaction pattern of hazelnut workers, which was not defined before in the literature. Defining the condition in the literature and performing further controlled field studies with larger series would help define and prevent the causes of the condition.

Keywords: Insect bites and strings, vasculitis, hazelnut

\section{Öz}

Amaç: Fındık, ülkemizin en önemli tarım ürünlerinden biridir. Türkiye'de fındık bahçelerinde yaklaşık olarak 150 böcek türü tespit edilmiştir. Fındık iş̧̧ilerinde böceklerle temas nedeniyle çeşitli deri reaksiyonları görülebilir. Bu çalışmanın amacı, fındık işçilerinde tespit edilen ve henüz rapor edilmemiş bir tür yaygın böcek ısırı̆̆ı reaksiyonunun klinik özelliklerini incelemektir.

Gereç ve Yöntem: Çalışmamızda fındık bahçesine girdikten sonra yaygın böcek ısııı̆ı reaksiyonu ile polikliniğimize başvuran tüm hastaları prospektif olarak inceledik. Hastaların yaşları, cinsiyetleri, lezyonların klinik özellikleri, vücuttaki yerleşim yerleri, subjektif semptomları, sayısı ve süresi, hastaların kan grubu ve verdiğimiz tedaviler kaydedildi. Ayrıca fındık bahçesi özellikleri de kaydedildi.

Bulgular: Çalışmaya 127 hasta (45 erkek, 82 kadın) alındı. Yaş ortalaması 42,5 516,69 'du. Lezyonlar en sık kalça $(\% 88,2)$, bacak (\%78,7) ve sırt-bel bölgesinde $(\% 72,4)$ gözlendi. Hastaların $\% 85^{\prime}$ inde violese papüller görülürken, $\% 10,2$ 'sinde papüler ürtiker, $\% 4,7^{\prime}$ 'sinde ise vaskülit benzeri purpurik papüller gözlendi. Hastaların \%59'unda 0-50 arası lezyon varken, \%28,4 hastada 50-100 arası, \%12,6 hastada ise 100 üzeri lezyon vardı. Hastaların \%97,6'sında şiddetli kaşıntı mevcuttu.
\end{abstract}

Address for Correspondence/Yazışma Adresi: Işıl Deniz Oğuz MD, Giresun University Faculty of Medicine, Department of Dermatology, Giresun, Turkey Phone: +90 5057226308 E-mail: isildenizoguz@yahoo.com.tr Received/Geliş Tarihi: 07.05.2020 Accepted/Kabul Tarihi: 16.12.2020 ORCID: orcid.org/0000-0001-8628-6107

Cite this article as: Oğuz ID, Kulaklı S, Akşan B. Disseminated insect bite reactions in hazelnut workers. Turkderm-Turk Arch Dermatol Venereol 2021;55:81-6.

(c) Copyright 2021 by Turkish Society of Dermatology and Venereology

Turkderm - Turkish Archives of Dermatology and Venereology published by Galenos Yayınevi. 
Sonuç: Böcek ısırığı reaksiyonu fındık işçilerinde görülen önemli bir sağlık sorunudur. Fındık bahçelerinde görülen arthropod kaynaklı dermatozlarla ilgili sınırlı sayıda çalışma vardır. Ancak biz çalışmamızda fındık işçilerinde görülen daha önce literatürde sunulmamış farklı klinik tipte bir böcek ısırı̆̆ı reaksiyonunu sunduk. Hastalığı tanımlayıp literatüre katmanın ve daha geniş kapsamlı ve kontrollü saha çalışmalarına ön ayak olmanın, etkenini bulmada ve etkenle mücadelede önemli bir adım olacağına inanıyoruz.

Anahtar Kelimeler: Böcek ısırıkları ve sokmaları, vaskülit, fındık

\section{Introduction}

An insect bite is a lesion created by the mouth part of an arthropod. However some insects can cause a skin reaction without biting. They can cause allergic reactions due to their stings, by injecting venom, or their bodies, droppings, or bodiliy fluids after skin contact ${ }^{1}$. A wide range of insects, such as mosquitoes, sand flies, house flies, fleas, bees, ants, spiders, ticks, and bedbugs, can cause various dermatological reactions. Those reactions vary according to the insect type and can range from mild to severe in a wide clinical spectrum, such as asymptomatic bite marks, erythematous itchy papules, papular urticaria, cellulite-like lesions, nodular lesions, bullous lesions, dermal edema, necrotizing ulcers, widespread urticaria, and even anaphylaxis ${ }^{1-3}$. Therefore, insect bite reactions are considered an important health issue.

Hazelnut is one of the most important agricultural products of Turkey. In the Black Sea Region, Giresun, Ordu, and Samsun provinces make up about $48 \%$ of the hazelnut production area in Turkey. Hazelnut harvest starts at the end of July and continues through August until the beginning of September. About 150 insect species were described in Turkey's hazelnut orchards ${ }^{4}$, and several skin reactions can be seen in hazelnut workers due to contact with the insects.

We noticed that every hazelnut harvest season in Giresun province, numerous patients presented to our outpatient clinic with similar skin complaints. Those patients had widespread, very itchy, erythematous, purplish, or vasculitis-like purpuric papular lesions, with or without insect bite marks in the middle. The lesions are mainly found on the hips, abdomen, back, legs, and thighs. Most of the patients reported experiencing this skin rash after sitting on the ground where the boars laid or slept before. Some patients had vasculitis-like purpuric papules. At first, we diagnosed these lesions as a severe type of cutaneous vasculitis. However, after the biopsy with vasculitis prediagnosis, we saw histopathological features compatible with insect bite reaction. Then, we noticed that there are no studies or case reports about this clinical condition in literature yet. Therefore, we aimed to describe this disseminated insect bite reaction, which is frequently seen in Giresun province and affects the local hazelnut farmers. Our secondary aim was to define the insect species causing this reaction if possible.

\section{Materials and Methods}

After obtaining the approval of the Institutional Ethical Committee of Giresun University Clinical Research (approval number: KAEK-70), the data of 127 patients were analyzed prospectively. All patients presenting to our outpatient clinic with the disseminated insect bite reactions described previously and who entered the hazelnut orchards between August 2019 and September 2019 were included. Informed consent was obtained from all patients. The patients' demographic properties, such as age, gender, and ABO blood group, were recorded. Clinical manifestations and number of lesions, areas of involvement, subjective symptoms, duration of symptoms, and treatments were also recorded.
The patients were asked the following questions. "Did you see any insects on your body or clothes?" "Which insect did you see?" "Did any of the people who entered the hazelnut orchard with you have similar complaints?" "Did you suffer from the same complaints in previous hazelnut harvesting seasons?" "Where was your hazelnut orchard?" "How was the weather during the harvest?" "Was the ground wet or dry?" "Did you sit on the ground in the hazelnut orchard?" "Did you sit where the boars had sat or slept?"

\section{Statistical Analysis}

SPSS 21.0 software was used in the statistical analysis. The frequency of data was shown as percentage slices. Kolmogorov-Smirnov test was used to check the normality of distribution of the variables. Descriptive statistics were expressed as median and minimum-maximum (min-max) ranges in variables without normal distribution and arithmetic mean \pm standard deviation in variables with normal distribution. Independent Sampling t-test was used to compare the age variable as it showed a normal distribution. Chi-square test was used to compare the blood types between the different clinic insect bite patterns. $P<0.05$ was considered significant.

\section{Results}

The study included 127 patients [82 (64.6\%) females and 45 (35.4\%) males]. Mean age of the patients was $42.5 \pm 16.7$ (9 months to 74 years). The mean age of males was $43.0 \pm 2.6$ (9 months to 70 years) and that of females was $42.2 \pm 1.8$ (5-74 years). No significant difference was found in terms of mean age between males and females $(p=0.5)$. On examining the skin lesions, we detected the following: Symmetrical purple/violaceous papules (some of them with crusts or bite marks in the middle) in 108 (85.0\%) patients, papular urticaria like symmetrical erythematous papules with edema (some of them with crusts or bite marks in the middle) in 13 (10.2\%) patients, and vasculitis-like purpuric papules (some of them with crusts or bite marks in the middle) in six (4.7\%) patients (Figure 1-3). Biopsies were taken from the vasculitislike lesions to differentiate vasculitis. Histopathological examinations of all biopsies showed insect bite reactions. None of the patients had secondary vasculitis on the histopathological examination.

One hundred and twenty-four (97.6\%) patients reported itching, six (4.7\%) reported burning, and one $(0.8 \%)$ reported pain as subjective symptoms. In all patients with burning and pain symptoms, purple/ violaceous papules were present. Lesions were symmetrically distributed. A patient reporting lying on his right side in the orchard had lesions on the right side of the body. On examining the area of involvement on the body, we noticed that $88.2 \%$ (112 patients) had lesions on the gluteal region. The lesions were present in other body regions as follows: The proximal leg in $78.7 \%$ (100) of the patients, back and waist in $72.4 \%$ (92) of the patients, trunk and abdominal area in $52.8 \%$ (67) of the patients, arms in $30.7 \%$ (39) of the patients, distal leg and ankle in $9.4 \%$ (12) of the patients, wrist in $7.1 \%$ (9) of 


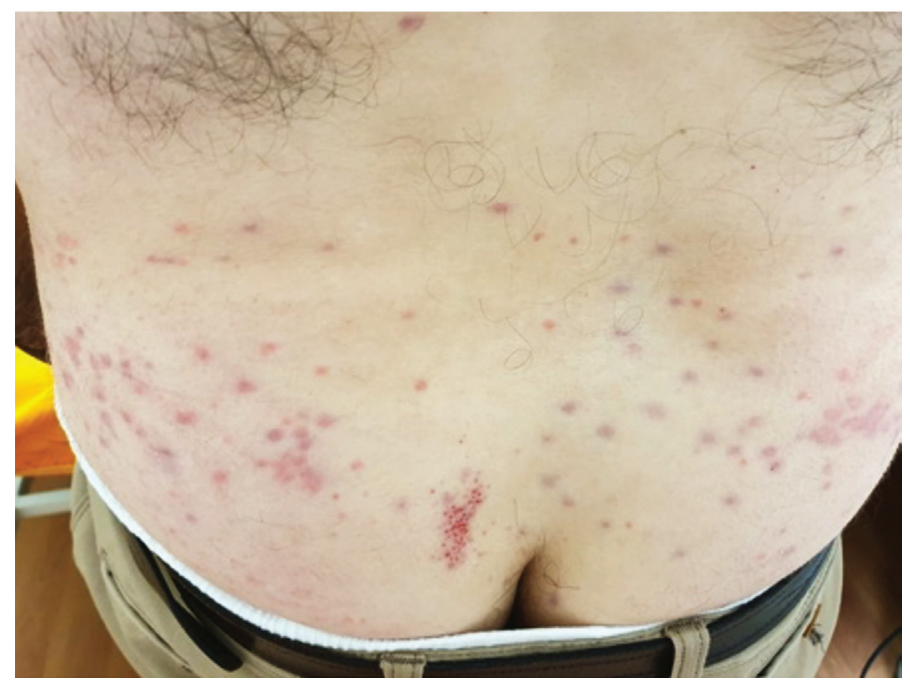

Figure 1. Symmetrical purple/violaceous papules on the gluteal region

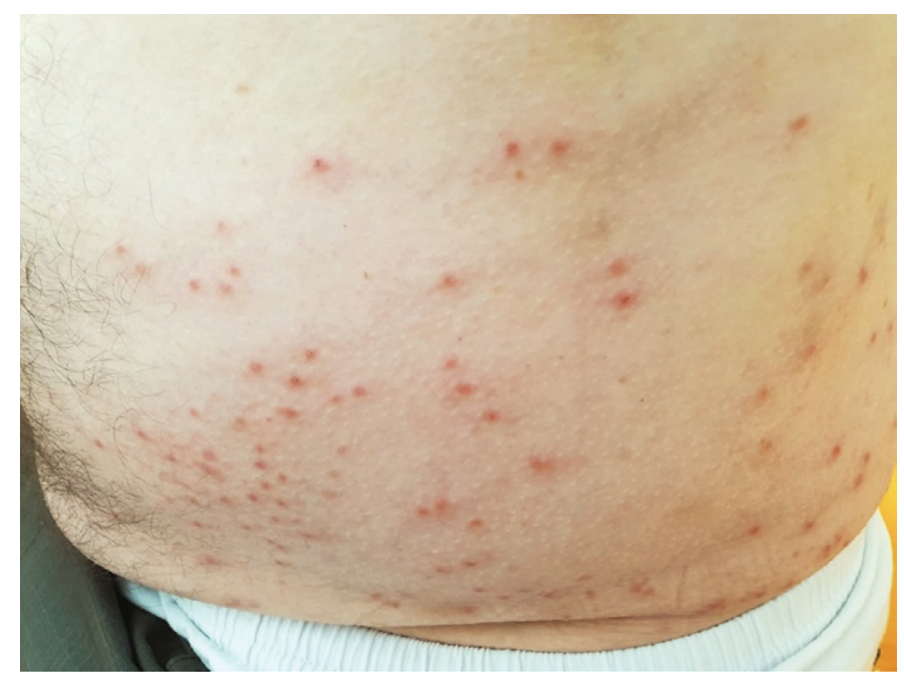

Figure 2. Symmetrical erythematous papules; some of them had crusts or bite marks in the middle

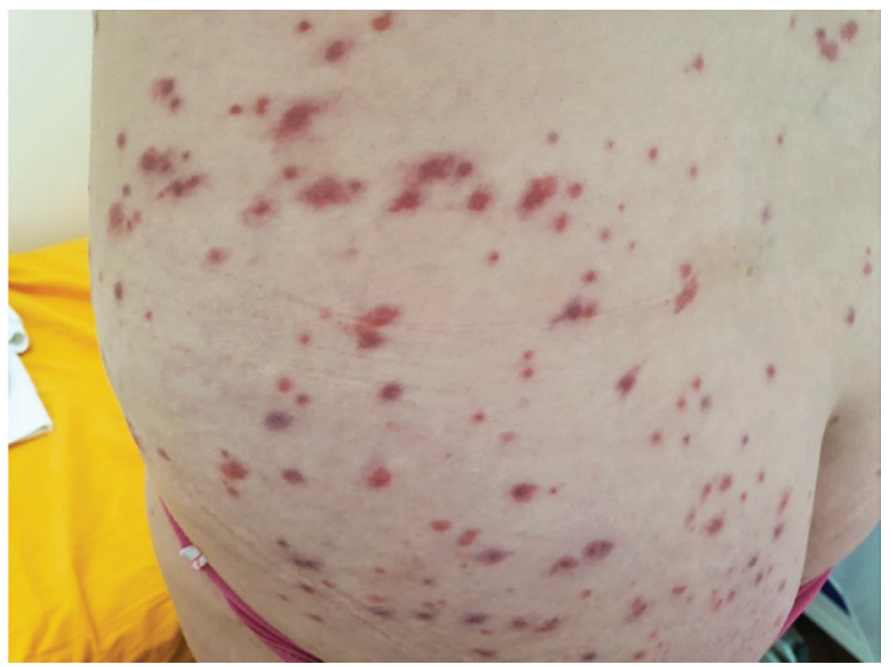

Figure 3. Vasculitis-like purpuric papules on the gluteal region the patients, and neck in $2.4 \%$ (3) of the patients. No lesions were seen on the head, palms, or soles of the feet. Nine (7.1\%) patients reported lesions on a single part of body, whereas 118 (92.9\%) had lesions on two or more body regions. When the number of lesions was assessed, 75 (59.1\%) patients had 0-50 lesions, whereas 36 (28.3\%) patients had 50-100 and 16 (12.6\%) patients had more than 100 lesions.

When blood groups were compared, the most common blood group was A Rh+ (29.9\%; 38 patients) followed by $0 \mathrm{Rh}+$ (26.0\%; 33 patients). The frequencies of the other blood types are as follows: A Rh- $4.7 \%$ (6 patients), B Rh+ 15.0\% (19 patients), B Rh- 4.7\% (6 patients), 0 Rh$3.9 \%$ (5 patients), $A B$ Rh+3.9\% (5 patients), and AB Rh- 0 patients. The blood types of 15 patients (11.8\%) were unknown. There was no statistically significant difference between the three insect bite patterns in terms of the blood groups ( $p=0.55$ ). No pathological markers were seen in the patients' routine hemogram and biochemical laboratory results.

All patients reported working in hazelnut orchards. Sixty-two patients (48.8\%) reported that their complaints began while in the orchard, 64 patients (50.4\%), when at home, and one (0.8\%) patient, on the highland. Four patients reported that they did not experience any symptoms when they were working on their own hazelnut orchards, yet symptoms occurred after they entered another orchard. Fifty-six patients (44.1\%) reported that their complaints began on the same day they entered the orchard. Median time between the complaints and orchard entrance was one day (min: 1 day; max: 10 days).

One hundred and twenty-three patients (96.9\%) reported sitting on the ground in the orchard. Eighty-one (63.8\%) patients reported sitting on the ground where the weeds were trampled; they call it "the place where the boars sat or slept." When questioned, 111 patients (87.4\%) reported no sighting of insects on their body or clothing. Sixteen patients reported seeing an insect. Five of the patients reported having no idea what the insect was, seven reported a type of tick called "sakirtlak" in the local dialect, one reported a spider, one reported an ant, one reported a fly-like winged insect, and one reported seeing a white insect. However, they reported that none of the insects bit them while they saw them. Sixty-five patients (51.2\%) reported hearing similar complaints from the people with whom they entered the orchard, and 62 patients (48.8\%) reported no complaints from their fellow workers. Forty patients (31.5\%) reported experiencing similar complaints in the previous years when they worked in hazelnut orchards, and 87 patients (68.5\%) reported these types of complaints for the first time this year. One hundred and two patients (79.5\%) were treated with oral antihistamines and topical corticosteroids, whereas the rest of the patients (26; 20.5\%) were treated with short-term systemic steroids. The majority of patients reported those complaints after hazelnut harvesting in the villages around Giresun central province (62 patients; 48.8\%). Other hazelnut orchard locations were reported: villages in Keşap (23 patients; 18.1\%), Bulancak (14 patients; 11.0\%), Piraziz (10 patients; 7.9\%), Tirebolu (6 patients; 4.7\%), Dereli (5 patients; 3.9\%), Espiye (4 patients; 3.1\%), Yağlıdere (2 patients; 1.6\%), and Güce (1 patient; 0.8\%) provinces. Seventy-five (59.1\%) patients reported that the orchards were bordered by a forest, whereas $52(40.9 \%)$ reported no such borders. Twenty-six patients $(20.5 \%)$ reported that the ground was wet when they entered the orchard, whereas 41 patients (32.3\%) reported that the ground was damp and 60 patients (47.2\%) reported that the ground was dry. Seventy-four patients (58.3\%) reported sunny weather during 
orchard work, whereas eight patients (6.3\%) reported cloudy conditions, 35 patients (27.6\%) reported rainy conditions, and 10 (7.9\%) patients reported both rainy and clear weather conditions (Table 1, 2).

\section{Discussion}

Skin reactions seen after insect bites are caused by the traumatic injury to the skin, local inflammation, and hypersensitivity against insect saliva or the insect's venom. Different clinical outcomes are seen according to the type of insect ${ }^{2}$. We reported the presence of symmetrical purple/ violaceous papules (some of them with crusts or bite marks in the middle) in 108 (85.0\%) patients, symmetrical papular urticaria like erythematous papules with edema (some of them with crusts or bite marks in the middle) in 13 (10.2\%) patients, and vasculitis-like purpuric papules (some of them with crusts or bite marks in the middle) in six (4.7\%) patients. The common clinical properties of those three types of lesions were that they were widespread, symmetrical, and frequently localized on gluteal and abdominal regions. Yet, they differed in lesion color and some of them had purpura. When we investigated insect bite reactions which resemble the skin lesions seen in our patients, we found out that bedbugs, fleas, and some mites can create similar reactions. Bedbugs live in dark places, such as wall cracks, beds, pillows, furniture, and flooring. They tend to feed on humans during nighttime, while they are asleep ${ }^{5}$. Three or more bite marks on the same region ("breakfast, lunch, and dinner" sign) might warrant a bedbug bite suspicion. Bedbug bites are usually more common on the open areas of the body, such as face, neck, hands, and arms ${ }^{6}$. The bedbug bite usually shows itself as an itchy bite without surrounding erythema. Apart from this, it can also manifest as papular urticaria with purpura in the center, bullous lesions, and rarely anaphylaxis caused by immunuglobulin E-mediated hypersensitivity against insect saliva $a^{2,6,7}$. The clinical appearance of our patients' lesions was similar to that of bedbug bites. Unlike bedbug bites findings, all our patients' complaints started after they entered the hazelnut orchard, and the lesion localizations were more bodycentric, such as in the glutes and abdomen, as opposed to open areas, such as face, neck, and hands.

Fleas are ectoparasites that feed on warm-blooded animals. Cats, dogs, wolves, and rats are host animals for those parasites ${ }^{8}$. There are also some reports on bites caused by pigeon and cat fleas, which can live on raccoons ${ }^{9,10}$. While sucking blood from their host, fleas lay their eggs among the host's feathers/hair. Humans are exposed to those parasites after having contact with those animals ${ }^{8}$. Saliva, feces, and other waste materials of fleas can produce allergic reactions. A papular urticaria lesion usually occurs at the bite site. Lesions might have a hemorrhagic and purpuric area in the middle. Fleas usually cause a large number of lesions on the open areas of the body, such as the ankles and legs $s^{2,11}$. In our patients, the characteristics and large number of lesions were similar to those of lesions caused by flea bites. The fact that $96.9 \%$ of the patients reported sitting on the ground in hazelnut orchards, and that $63.8 \%$ of them sat down on a grassy patch, which they described as "the place where the boars sat or slept," led us to believe that these lesions can be caused by a flea species that uses wild boars as a host. A study done in Argentina reported that domesticated pigs can harbor Ctenocephalides felis and Pulex irritans ${ }^{12}$. Moreover, wild boars were reported to have other ectoparasites, such as mites, sarcoptes, and fleas $^{13-15}$

Mites have a large number of subtypes ${ }^{5}$. The larvae of the harvest mites from the Trombiculidae family, also known as "chiggers," can cause a group of skin lesions due to a hypersensitivity reaction against digestive enzymes during feeding ${ }^{16}$. Those mites can survive in various parts of the world, including Turkey in the Black Sea Region ${ }^{16,17}$. They live on damp and grassy ground and they usually form localized mite islets on vegetation. They have a life span of five to seven months with proper

\section{Table 1. Demographic and clinical features of patients}

\begin{tabular}{|c|c|c|}
\hline \multicolumn{2}{|c|}{ Mean age $($ mean $\pm S D)$} & \multirow{2}{*}{$\begin{array}{l}42.47 \pm 16.69 \\
45(35.4)\end{array}$} \\
\hline Condor & Female, $\mathrm{n}(\%)$ & \\
\hline Serraer & Male, n(\%) & $82(64.6)$ \\
\hline \multirow{3}{*}{$\begin{array}{l}\text { Lesion } \\
\text { features }\end{array}$} & Purple/violaceous papules, n(\%) & $108(85.0)$ \\
\hline & Papular urticaria, n(\%) & $13(10.2)$ \\
\hline & $\begin{array}{l}\text { Vasculitis-like purpuric } \\
\text { papules, }(\mathrm{n} \%)\end{array}$ & $6(4.7)$ \\
\hline \multirow{9}{*}{$\begin{array}{l}\text { Lesions } \\
\text { localizations }\end{array}$} & Head, $n(\%)$ & 0 \\
\hline & Neck, n(\%) & $3(2.4)$ \\
\hline & Body front and abdomen, $\mathrm{n}(\%)$ & $67(52.8)$ \\
\hline & Body back and waist, $n(\%)$ & $92(72.4)$ \\
\hline & Gluteal region, $\mathrm{n}(\%)$ & $112(88.2)$ \\
\hline & Arms, $n(\%)$ & $39(30.7)$ \\
\hline & Legs, n(\%) & $100(78.7)$ \\
\hline & Wrists and hands, $\mathrm{n}(\%)$ & $9(7.1)$ \\
\hline & Ankles and feet, $n(\%)$ & $12(9.4)$ \\
\hline \multirow{11}{*}{$\begin{array}{l}\text { Number of } \\
\text { lesions }\end{array}$} & $0-10, n(\%)$ & $1(0.8)$ \\
\hline & $10-20, n(\%)$ & $15(11.8)$ \\
\hline & $20-30, n(\%)$ & $30(23.6)$ \\
\hline & $30-40, n(\%)$ & $15(11.8)$ \\
\hline & $40-50, n(\%)$ & $14(11.0)$ \\
\hline & $50-60, n(\%)$ & $18(14.2)$ \\
\hline & $60-70, n(\%)$ & $3(2.4)$ \\
\hline & $70-80, n(\%)$ & $8(6.3)$ \\
\hline & $80-90, n(\%)$ & $5(3.9)$ \\
\hline & $90-100, n(\%)$ & $2(1.6)$ \\
\hline & $>100, n(\%)$ & $16(12.6)$ \\
\hline \multirow{8}{*}{$\begin{array}{l}\text { Number of } \\
\text { affected body } \\
\text { areas }\end{array}$} & 1 body area, $n(\%)$ & $9(7.1)$ \\
\hline & 2 body area, $\mathrm{n}(\%)$ & $22(17.3)$ \\
\hline & 3 body area, $n(\%)$ & $36(28.9)$ \\
\hline & 4 body area, $n(\%)$ & $38(29.9)$ \\
\hline & 5 body area, $n(\%)$ & $15(11.8)$ \\
\hline & 6 body area, $n(\%)$ & $3(2.4)$ \\
\hline & 7 body area, $n(\%)$ & $2(1.6)$ \\
\hline & 8 body area, $n(\%)$ & $2(1.6)$ \\
\hline \multirow{3}{*}{ Symptom } & Itching, n(\%) & $124(97.6)$ \\
\hline & Pain, $n(\%)$ & $1(0.8)$ \\
\hline & Burning, $n(\%)$ & $6(4.7)$ \\
\hline
\end{tabular}


Table 2. Characteristics of patients, orchards, and climates at the time of entering the orchards

\begin{tabular}{|l|l|l|}
\hline \multicolumn{2}{|l|}{} & $\begin{array}{l}\text { Number of } \\
\text { patients (\%) }\end{array}$ \\
\hline \multirow{2}{*}{$\begin{array}{l}\text { The place where the } \\
\text { complaints began }\end{array}$} & Hazelnut orchards & $62(48.8)$ \\
\cline { 2 - 3 } & House & $64(50.4)$ \\
\cline { 2 - 3 } & Highland & $1(0.8)$ \\
\hline Number of patients entering the hazelnut orchards & $127(100)$ \\
\hline $\begin{array}{l}\text { Number of patients with the same complaints in } \\
\text { previous years }\end{array}$ & $40(31.5)$ \\
\hline $\begin{array}{l}\text { Number of patients who reported similar complaints } \\
\text { from their fellow workers }\end{array}$ & $65(51.2)$ \\
\hline $\begin{array}{l}\text { Number of patients who sat on the ground in the } \\
\text { orchard }\end{array}$ & $123(96.9)$ \\
\hline \multirow{2}{*}{$\begin{array}{l}\text { Number of patients who sat on the ground where } \\
\text { the boars had sat }\end{array}$} & $81(63.8)$ \\
\hline Patients whose garden has a border with the forest & $75(59.1)$ \\
\hline \multirow{2}{*}{ Ground condition of the orchard } & Wet & $26(20.5)$ \\
\cline { 2 - 3 } & Damp & $41(32.3)$ \\
\cline { 2 - 3 } & Dry & $60(47.2)$ \\
\hline \multirow{2}{*}{$\begin{array}{l}\text { Weather at the time the patients } \\
\text { entered the orchards }\end{array}$} & Sunny & $74(58.3)$ \\
\cline { 2 - 3 } & Cloudy & $8(6.3)$ \\
\cline { 2 - 3 } & Rainy & $35(27.6)$ \\
\cline { 2 - 3 } & Sunny + rainy & $10(7.9)$ \\
\hline
\end{tabular}

living conditions. However, they only show parasitic activity during their larval form. The skin reaction they cause is called trombiculiasis. It is reported to be caused by either direct contact with mite islets or contact with infected animals, such as dogs or cats. The larvae, which hatched from the eggs left on soil, attach to the skin and migrate to skin areas suitable for feeding. The feeding period on humans can vary from three to eight hours to one to two days, and the larvae stays on the skin during that period ${ }^{16}$. Tight clothing and clothing tires can prevent this migration. Therefore, those lesions are usually focused on the places where the clothing constricts the body such as around the waist and wrists or ankles. In addition, the lesions may be located at the knees, antecubital fossa, thigh, inguinal area, and axillary region ${ }^{16,18}$. Lesions are observed as a large number of itchy papules and pustules ${ }^{18}$. The larvae are too small to be noticed with the naked eye; however, it can sometimes be detected using a dermatoscope ${ }^{19}$. In our patients, the fact that the skin lesions were accumulated on areas such as waist and hips made us believe that this could be the culprit. However, trombiculiasis is characterized by large numbers of papules and pustules, and none of our patients had any pustules. The lesions found in our patients were mainly violaceous-erythematous or purpuric papules.

Gluteal involvement was found in $88.2 \%$ of the patients, whereas proximal leg involvement was found in $78.7 \%$. This might be explained by the fact that the patients were sitting on the ground, and the causative factor created lesions on the body regions that touched the ground. However, as the parts of the body contacting the ground were covered with clothing, the vector would have to enter through the exposed parts, such as arms, legs, or neck, or create a puncture through clothing on the skin. This contradicts our initial hypothesis.
The most frequent blood groups among patients were A Rh+ and $0 \mathrm{Rh}+$. Some studies showing that Anopheles gambiae mosquitoes prefer feeding on people with 0 blood type ${ }^{20,21}$. In another study, it was shown that Aedes albopictus mosquitoes also preferred feeding on people with 0 blood type compared with people with A blood type ${ }^{22}$. Based on these studies, we wanted to examine the distribution of blood groups in our patients. The most common blood group was $A$ $\mathrm{Rh}+(29.9 \%)$ followed by $0 \mathrm{Rh}+(26.0 \%)$. These findings do not mean that, in our study, the vectors preferred people with A blood type compared with the others. The blood group distribution was similar to the Eastern Black Sea region population ${ }^{23}$. There was no statistical difference between the three clinical groups of our patients and the blood groups.

When we reviewed the literature, we came across three published studies on dermatoses caused by arthropods in hazelnut farmers. The first study was a case report on three patients with cutaneous larva migrans in Düzce region ${ }^{24}$. Another study conducted in Giresun province included 46 patients diagnosed with Paederus dermatitis. All patients reported having lesions after entering hazelnut orchard ${ }^{25}$. The third study was on tick bites in hazelnut farmers in Giresun province. One hundred and forty-six live ticks were collected from 134 hazelnut workers. Most of the collected ticks were identified as Ixodes ricinus (99.35\%). Ixodes spp. is an important vector for Lyme disease. In this study Borrelia spp, which causes Lyme disease, were identified in 3.4\% of the cultures ${ }^{26}$. However, we could not find any studies on insect bite patterns in hazelnut workers demonstrated in our study.

\section{Study Limitations}

One of the most important limitations of our study was that we were unable to work in the field and we could not identify the vector that causes this condition. We only examined the patients who presented to our outpatient clinic, so we could not detect the prevalence of this condition.

\section{Conclusion}

Insect bite reactions are an important health issue seen in the hazelnut workers in Giresun province. There are limited numbers of studies on arthropod-induced dermatoses in hazelnut orchards. However, we demonstrated a novel insect bite reaction pattern in hazelnut workers, which was not defined before in the literature. Defining the condition in the literature and performing further controlled field studies with larger series would help define and prevent the cause of the condition.

\section{Ethics}

Ethics Committee Approval: After obtaining the approval of the Institutional Ethical Committee of Giresun University Clinical Research (approval number: KAEK-70), the data of 127 patients were analyzed prospectively.

Informed Consent: Signed informed consent documents were provided by all study participants.

Peer-review: Externally peer-reviewed.

\section{Authorship Contributions}

Surgical and Medical Practices: I.D.O., S.K., B.A., Concept: I.D.O., S.K., B.A., Design: I.D.O., S.K., B.A., Data Collection or Processing: I.D.O., S.K., B.A., Analysis or Interpretation: I.D.O., Literature Search: I.D.O. Writing: I.D.O. 
Conflict of Interest: No conflict of interest was declared by the authors.

Financial Disclosure: The authors declared that this study received no financial support.

\section{References}

1. Singh S, Mann BK: Insect bite reactions. Indian J Dermatol Venereol Leprol 2013;79:151-64

2. Powers J, McDowell RH: Insect Bites. 2020 Nov 21. In: StatPearls [Internet] Treasure Island (FL): StatPearls Publishing, 2021.

3. Halpert E, Borrero E, Ibañez-Pinilla $M$, et al: Prevalence of papular urticaria caused by flea bites and associated factors in children 1-6 years of age in Bogotá, D. World Allergy Organ J 2017;10:36.

4. AK K, Uysal M, Tuncer C: Bark beetle (coleoptera: scolytidae) species which are harmful in hazelnut orchards, their short biology and densities in Giresun, Ordu and Samsun provinces of Turkey. J Agric OMU 2005;20:37-44.

5. Steen CJ, Carbonaro PA, Schwartz RA: Arthropods in dermatology. J Am Acad Dermatol 2004;50:819-44.

6. Peres G, Yugar LBT, Haddad Junior V: Breakfast, lunch, and dinner sign: a hallmark of flea and bedbug bites. An Bras Dermatol 2018;93:759-60.

7. deShazo RD, Feldlaufer MF, Mihm MC Jr, Goddard J: Bullous reactions to bedbug bites reflect cutaneous vasculitis. Am J Med 2012;125:688-94.

8. Anderson J, Paterek E: Flea Bites. 2020 Aug 10. StatPearls [Internet]. Treasure Island (FL): StatPearls Publishing; 2021.

9. Haag-Wackernagel $D$, Spiewak R: Human infestation by pigeon fleas (Ceratophyllus columbae) from feral pigeons. Ann Agric Environ Med 2004;11:343-6.

10. Hunter KW Jr, Campbell AR, Sayles PC: Human infestation by cat fleas, Ctenocephalides felis (Siphonaptera: Pulicidae), from suburban raccoons. J Med Entomol 1979;16:547

11. Youssefi MR, Ebrahimpour S, Rezaei M, Ahmadpour E, Rakhshanpour A, Rahimi MT: Dermatitis caused by Ctenocephalides felis (cat flea) in human. Caspian J Intern Med 2014;5:248-50.

12. Sanchez JP, Ezquiaga MC, Ruiz M: Fleas (Insecta: Siphonaptera) with public health relevance in domestic pigs (Artiodactyla: Suidae) from Argentina. Zootaxa 2018:4374:144-50.
13. Leulmi H, Aouadi A, Bitam I, et al: Detection of Bartonella tamiae, Coxiella burnetii and rickettsiae in arthropods and tissues from wild and domestic animals in northeastern Algeria. Parasit Vectors 2016;9:27.

14. Cleveland CA, Swanepoel L, Box EK, De Nicola A, Yabsley MJ: Rickettsia species in ticks collected from wild pigs (Sus scrofa) and Philippine deer (Rusa marianna) on Guam, Marianna Islands, USA. Acta Trop 2019;194:8992.

15. Haas $C$, Origgi $F C$, Akdesir $E$, et al: First detection of sarcoptic mange in free-ranging wild boar (Sus scrofa) in Switzerland. Schweiz Arch Tierheilkd 2015;157:269-75

16. Santibáñez $P$, Palomar AM, Portillo $A$, Santibáñez $S$, Oteo JA: The role of chiggers as human pathogens. An Overview of Tropical Diseases 2015;173202.

17. Cakiroglu D, Pekmezci D, Meral Y, Gokalp G, Acici M: Trombiculidae larvae (Neotrombicula autumnalis) infestation in a Little Bittern (Ixobrychus minutus) in Turkey. Parasitol Res 2008;102:1077-9.

18. Woloski JR, Burman D, Adebona O: Mite and bed bug infections. Prim Care 2018;45:409-21.

19. Kaya TI, Yilmaz MA: Dermoscopy confirmed Trombiculidae larva infestation in Turkey. Int J Dermatol 2019;58:120-1.

20. Wood CS, Harrison GA, Doré C, Weiner JS: Selective feeding of Anopheles gambiae according to ABO blood group status. Nature 1972;239:165.

21. Wood CS: Preferential feeding of Anopheles gambiae mosquitoes on human subjects of blood group O: A relationship between the $\mathrm{ABO}$ polymorphism and malaria vectors. Hum Biol 1974;16:385-404

22. Shirai Y, Funada H, Takizawa H, Seki T, Morohashi M, Kamimura K: Landing preference of Aedes albopictus (Diptera: Culicidae) on human skin among $\mathrm{ABO}$ blood groups, secretors or nonsecretors, and $\mathrm{ABH}$ antigens. J Med Entomol 2004;41:796-99.

23. Ozkasap S, Dereci S, Şahin K, et al: Analysis of $A B O$ and Rh blood groups distribution in East Karadeniz region of Turkey. Dicle Med J 2013;40:100-4.

24. Çalışan E, Uslu E, Turan H, Başkan E, Klıç N: Cutaneous larva migrans: report of three cases from the Western Black Sea Region, Turkey. Mikrobiyol Bul 2016:50:165-9.

25. Uzunoğlu E, Oguz ID, Kir B, Akdemir C: Clinical and Epidemiological Features of Paederus Dermatitis Among Nut Farm Workers in Turkey. Am J Trop Med Hyg 2017;96:483-7.

26. Uzunoglu E, Polat E, Oguz ID, et al: Tick bite cases among hazelnut farm workers in Giresun. Cumhuriyet Med J 2017;39:473-8. 